\title{
Influence of early use of antimicrobial on the health and performance of Holstein calves in the first month of life ${ }^{1}$
}

\author{
Camila C. Martin²* (D), Natália S. Basqueira², Jean S. Ramos² (D), Karen N. Silva² (D), \\ Camila C. Baccili ${ }^{2}$ (D), Paulo E. Brandão ${ }^{3}$ and Viviani Gomes ${ }^{2}$
}

\begin{abstract}
Martin C.C., Basqueira N.S., Ramos J.S., Silva K.N. Baccili C.C., Brandão P.E. \& Gomes V. 2020. Influence of early use of antimicrobial on the health and performance of Holstein calves in the first month of life. Pesquisa Veterinária Brasileira 40(1):17-28. Departamento de Clínica Médica, Faculdade de Medicina Veterinária e Zootecnia, Universidade de São Paulo, Av. Orlando Marques de Paiva 87, Cidade Universitária, Butantã, SP 05508-270, Brasil. E-mail: camilacmartin@gmail.com

The early use of antimicrobial therapy has been introduced in many farms to prevent diarrhea and respiratory disease in young calves; however, there is controversy about whether this practice has a beneficial effect on the health of these animals. This study evaluated the influence of the early use of antimicrobials on the health and performance of neonatal Holstein calves. Twenty-six Holstein calves were screened and divided into two groups, according to the administration (ATB+), or not (ATB-) of tulathromycin $(2.5 \mathrm{mg} / \mathrm{kg}$, subcutaneously) within the first 12 hours of life. Calves were evaluated by general clinical examination, fecal score, respiratory score, and external palpation of the umbilical region, besides fecal output of dry matter. Anemia was determined by using an automatic system and, also, using a commercial kit for iron dosage. Diarrhea was diagnosed by a centrifuge-flotation technique using a sugar solution (Cryptosporidium) and multiplex semi-nested RT-PCR (rotavirus/coronavirus). The performance of the calves was estimated by Daily Weight Gain (DWG). The young dairy calves were evaluated within 12 hours of birth ( $\leq 12 \mathrm{~h}$ ) and at 3-5th (D3-5), 7-9th (D7-9), 13-15th (D13-15), 20-23rd (D20-23), and 27-30th (D27-30) days of life. No difference was noted between the ATB+ and ATB- groups concerning heart rate, respiratory frequency, and rectal temperature. Erythrogram showed a higher frequency of anemia in ATB- group ( $\mathrm{P}=0.016)$ at the $\mathrm{D} 3-5$ check-up; lower values of serum iron were also observed simultaneously $(\mathrm{P}=0.051)$. Thirteen cases of respiratory disease were detected during this study; however, no significant difference was observed between the groups in this regard. The frequency of diarrhea (fecal score 2-3) was high in both groups, peaking at D13-D15. No differences were noted between the groups regarding the frequency of diarrhea when considering the dry fecal matter. The predominant etiological agent for diarrhea was Cryptosporidium spp.. The DWG was similar between groups, with maximum weight reduction on D13-15. The administration of tulathromycin in prophylactic dose $(2.5 \mathrm{mg} / \mathrm{kg})$ at birth decreased the frequency of anemia but did not influence weight gain or the prevalence of diarrhea.
\end{abstract}

INDEX TERMS: Antimicrobial, health, performance, Holstein calves, tulathromycin, prophylaxis, sanity, cattle.

\footnotetext{
${ }^{1}$ Received on April 13, 2019.

Accepted for publication on June 6, 2019.

${ }^{2}$ Departamento de Clínica Médica, Universidade de São Paulo (USP), Av. Orlando Marques de Paiva 87, Cidade Universitária, Butantã, SP 05508-270, Brazil. *Corresponding author: camilacmartin@gmail.com

${ }^{3}$ Departamento de Medicina Veterinária Preventiva e Saúde Animal, Universidade de São Paulo (USP), Av. Orlando Marques de Paiva 87, Cidade Universitária, Butantã, SP 05508-270.
}

RESUMO.- [Influência do uso precoce de antimicrobiano na sanidade de bezerras holandesas no primeiro mês de vida.] 0 uso precoce de antimicrobianos tem sido adotado em muitas fazendas para profilaxia das diarreias e doença respiratória em bezerras, no entanto existem controvérsias sobre os beneficios desta prática na saúde desses animais. Esta 
pesquisa avaliou a influência do uso precoce de antimicrobiano na sanidade e desempenho de bezerras holandesas recém-nascidas. Para tanto foram selecionadas 26 bezerras Holandesas distribuídas de acordo com a aplicação (ATB+) ou não (ATB-) de tulatromicina $(2,5 \mathrm{mg} / \mathrm{Kg})$ por via subcutânea até $12 \mathrm{~h}$ de vida. As bezerras foram examinadas por meio de exame clínico geral, escore fecal, escore respiratório e palpação externa da região umbilical, além da matéria seca fecal. A presença de anemias foi determinada pelo eritrograma utilizando sistema automático e além da dosagem de ferro utilizando kit comercial. 0 diagnóstico etiológico das diarreias foi investigado por meio da técnica de flutuação em solução saturada de sacarose (Cryptosporidium) e multiplex semi-nested RT-PCR (rotavírus/coronavírus). 0 desempenho das bezerras foi estimado pelo ganho de peso. As bezerras foram avaliadas até doze horas após o nascimento ( $\leq 12 \mathrm{~h}$ ); 3-5으 (D3-5); 7-9o (D7-9); 13-15 (D13-15); 20-23으 (D20-23); e 27-30을 dias de vida (D27-30). Não foram encontradas diferenças entre os grupos ATB+ e ATB- em relação à frequência cardíaca, frequência respiratória e temperatura retal. 0 eritrograma revelou maior frequência de anemias no grupo ATB- $(\mathrm{P}=0,016)$ no D3-5. Neste momento também foram observados menores valores de ferro sérico $(\mathrm{P}=0,051)$. Foram detectados treze casos de doença respiratória durante o estudo, no entanto não foi possível detectar diferença entre os grupos. A frequência de diarreias (escore fecal 2 e 3 ) foi alta em ambos os grupos, observando-se pico no D13-15 (ATB+=92,3\%; ATB-=92,3\%). Não observamos diferenças entre os grupos em relação a frequência de diarreia considerando-se a matéria seca fecal. $\mathrm{O}$ agente etiológico predominante nas diarreias foi o Cryptosporidium. 0 ganho de peso diário foi igual entre grupos, com intensa redução no GPD no D13-15. A administração de tulatromicina na dose profilática $(2,5 \mathrm{mg} / \mathrm{Kg})$ ao nascimento diminuiu a frequência de anemias e não influenciou no ganho de peso e prevalência de diarreias.

TERMOS DE INDEXAÇÃO: Antimicrobiano, bezerras holandesas, desempenho, tulatromicina, profilaxia, sanidade, bovinos.

\section{INTRODUCTION}

The cost of the 22- to 24-month calf production cycle is around \$1124.06, being the second only for the cost of feeding lactating cows. All this investment, in addition to expressing the maximum genetic potential of females, can be diluted by nutritional and health management errors (Gabler et al. 2000, Heinrichs \& Heinrichs 2011). Increasing age at first calving is related to the treatment of antimicrobial diseased calves (Heinrichs et al. 2005); also the number of days of disease or treatment before four months of age significantly alters milk production in the first lactation (Heinrichs \& Heinrichs 2011).

Calves are born hypogammaglobulinemia and have an adaptive näive immune system, and are immunosuppressed due to the interaction between hormones and cytokines present in the maternal-fetal environment. Due to these factors, the postnatal immune response is slow and low in intensity, making these animals dependent on maternal protection transferred by colostrum and susceptible to management errors that predispose to the establishment of agents that cause diarrhea, umbilical inflammation and bronchopneumonia (Barrington \& Parish 2001, Chase et al. 2008). Morbidity from diarrhea in neonatal calves can be as high as 90 to $100 \%$ in animals up to three weeks of age and the mortality rate observed in the suckling phase is approximately $3.5 \%$, with a peak death rate around 19 days of age life (Langoni et al. 2004, Windeyer et al. 2014).

In an attempt to decrease mortality, improve health, and increase performance, many producers use long-acting prophylactic antimicrobials because of the difficulty in early identification of sick animals (Ives \& Richeson 2015). Prophylactic use of antimicrobials has been widely used in confinements for respiratory disease prophylaxis, and there are currently eight injectable antimicrobials (danofloxacin, enrofloxacin, tulathromycin, ceftiofur, tilmicosin, florfenicol, tildipirosin and gamithromycin), plus four oral antimicrobials (oxytetracycline, tilmicosin, chlortetracycline (CTC), and CTC in combination with sulfadiazine (SDZ), internationally approved for prophylactic use for respiratory disease in cattle (Ives \& Richeson 2015).

Antimicrobials have also been ostensibly used to treat or prevent diarrhea in calves. Walker et al. (2012), in a study in the United States of America (USA) by evaluating antimicrobial practices on dairy farms, found that $83 \%$ of the animals were treated with diarrhea antimicrobials, and $50 \%$ of calves diarrhea received more than one antimicrobial type. The authors also found that $56 \%$ of the properties used antimicrobial milk, and $54 \%$ of the properties used antimicrobials to prevent diarrhea or respiratory disease. Only $65 \%$ of the farms had written guidelines on the use of antimicrobials to treat the main diseases affecting calves.

The complexity of etiology of diarrhea in neonatal calves has been the basis for questions about the cost and benefit of antimicrobial use for prophylaxis of this disease. Diarrhea is caused by different groups of microorganisms among which some pathotypes of Escherichia coli (from 15.6 to 28.5\%), rotavirus (from 3.5 to $6.2 \%$ ), coronavirus (from 3.1 to $21.6 \%$ ), Salmonella spp. (from 16.4 to $43.7 \%$ ) and Cryptosporidium spp. (100 and 75\%) (Silverlås et al. 2010, Carvalho et al. 2014, Gomez et al. 2017). The benefit of the therapeutic use of antimicrobials for cases of enteritis due to Salmonella spp. or $E$. coli is distinct; however, there is no argument for its use in cases of rotavirus, coronavirus, and cryptosporidiosis (Berge et al. 2009, Smith 2015).

The use of antimicrobials affects not only harmful bacteria but also commensal and symbiotic bacteria that gradually colonize the gut in the postnatal period. Recent studies in humans have shown that the intestinal microbiota has a lot of benefits to the host, especially related to energy metabolism through digestion of undigested carbohydrates, production of vitamins B and $\mathrm{K}$, antibacterial and immunomodulatory activities, through different mechanisms: competition for binding sites; physiologically restricted environment production ( $\mathrm{pH}$ and $\mathrm{O}_{2}$ pressure); production of antimicrobial substances; formation of the intestinal barrier by mucin production, reducing the permeability of the epithelium; development of immune tolerance to commensal/symbiotic microorganisms and immune response to harmful bacteria (Wang et al. 2012, Aziz et al. 2013, Fernández et al. 2013, Vaziri et al. 2015). Thus the balance of the intestinal microbiota, as well as its diversity, has been associated with intestinal health.

Despite the many studies already conducted on the use of antimicrobials for calves, primarily associated with milk, these studies presented conflicting data regarding their 
efficacy. Berge et al. (2009) demonstrated that the use of antimicrobial supplemented milk increased the risk for diarrhea development by $28 \%$, decreased weight gain, and concentrate intake. However, Donovan et al. (2002) found no differences in performance and incidence of diarrhea in calves fed antimicrobial supplemented milk.

Besides, the influence of antimicrobials on immunity and health and their misuse has been associated with the selection and spread of resistant bacteria. Resistance is not a problem in itself, but the transfer of resistance elements to zoonotic pathogens has severe implications for human and animal health (Kaneene et al. 2008, Smith 2015). Once resistance is established in non-pathogenic bacteria, they can transfer these genes via plasmids and integrons to pathogenic organisms. Gene transfer that gives the pathogen selective host advantage has the potential to be rapidly spread within the bacterial population (Kaneene et al. 2008).

The current concern with the use of antimicrobials for disease prophylaxis and metaphylaxis in newborn calves has encouraged the scientific community to seek explanations about their real effect on the development of these animals and their implications for animal health and welfare (Berge et al. 2009, Smith 2015). Much research has been conducted to evaluate the parenteral use of long-acting antimicrobials in the prevention of respiratory disease in confined cattle, but little is said about their effect on newborn calves, especially their impact on intestinal health. Thus, this research aimed to investigate the influence of early parenteral antimicrobial use on the health profile and performance of calves in the neonatal period.

\section{MATERIAL AND METHODS}

Farm and Animals. This research was approved by the Animal Use Ethics Committee of "Faculdade de Medicina Veterinária e Zootecnia" of Universidade de São Paulo (USP), protocol no. 2596070715.

The calves of this research were from a high production commercial farm located in the state of São Paulo. The field phase of the study was conducted from May to July 2016. The farm had assisted births in farrowing stalls with adequate hygiene and colostration conditions, in addition to breastfeeding with pasteurized milk and without antimicrobials associated with raising calves in individual suspended stalls with periodic hygiene and disinfection.

Cows that were near the expected date of calving were transferred from the pre-calving paddock to sand-bed maternity pens where they remained until calving. Staff veterinarians or farm collaborators monitored all deliveries. Soon after birth, the calves were separated from the cows and transferred to the transitional stalls, where navel healing and bottle-feeding were performed.

The cows were milked in the stalls by individual mechanical milking, after cleaning the ceilings with a chlorinated solution and drying with individual paper towels. All colostrum supplied to calves was assessed for immunological quality by indirect evaluation of immunoglobulin concentration by colostrum balls (Ms colostrum balls, Nutri Support ${ }^{\oplus}, 3705010$ ) (density 1045-1075) and Brix refractometer (Model 300001; SperScientific, Scottsdale/AZ) $\left(23-32^{\circ}\right)$. Calf colostration was performed as soon as possible after birth, with the first breastfeeding given at the latest at six hours of life and the second generally performed within 6 hours of the first breastfeeding, according to the calf's need. Calves were given a minimum volume of colostrum equivalent to $10 \%$ of live weight.
Navel healing was performed shortly after birth by complete immersion of the umbilical cord in a container containing commercial antiseptic solution based on iodoform, phenol, picric acid, and dichlorvos (DDVP) (Umbicura - Pec ${ }^{\circledR}$ ) for $1 \frac{1}{2}$ minutes, repeating the process after 12 hours. This process was repeated twice a day until complete umbilical cord mummification occurred around eight to 10 days of life of the calves.

Healthy heifers from eutocic calves were selected for this research. Twenty-six calves were randomly assigned to two groups of 13 animals: Group 1- received a dose of tulathromycin antimicrobial $(2.5 \mathrm{mg} / \mathrm{Kg})$ subcutaneously, in the caudal thoracic region, the right scapula, up to twelve hours after birth (ATB+); Group 2- received a dose of physiological solution, subcutaneously up to twelve hours after birth (ATB-).

Stool specimens were evaluated and collected at the following times: up to twelve hours after birth $(\leq 12 \mathrm{~h}) ; 3-5$ th day of life (D3-5); 7-9th day of life (D7-9); 13th -15th day of life (D13-15); 20-23rd day of life (D20-23); and 27-30th days after birth (D27-30). The choice of these intervals was based on the dynamics of the main events and conditions affecting calves in the neonatal period. By 12 hours after birth, most calves were still eliminating meconium, at D3-5 is the period when animals are transferred from Maternity Pens (MP) to the calf after colostration and have a higher frequency of umbilical disorders, D7-9 to D13-15 is the peak of diarrhea, and from D20-23 to D27-30, post-diarrhea follow-up was performed.

The calves remained in the transitional pens for approximately three days, receiving only colostrum and transitional milk in the bottle, and were offered around three liters of transitional milk per breastfeeding. After this period, the calves were transferred to the hutches, where they remained until weaning. In the hutches, the calves were kept in individual stalls suspended from metal and wood with hay beds and were fed by bucket twice a day with a total of six liters of milk from postpartum cows. In the case of milk shortage, replacer (Natimilk, Auster ${ }^{\circledR}$ ) was used to complete daily milk volume, and the same replacement volume was used for all calves. Also, the calves received commercial feed and water ad libitum. These products contained no antimicrobial residues and growth promoters. All calves from four to six days old were dehorned using caustic paste.

Periodic clinical evaluation. Calves were evaluated at all times by clinical examination, assessing vital functions, and mucosal coloration (Feitosa 2014). The diarrhea score was also used according to the Calf Heath Scoring Criteria of University of Wiscosin - Madison (McGuirk 2008).

The stool score was classified from 0 to 3 according to fecal consistency, being 0 - normal consistency, 1 - pasty and semi-formed consistency, 2 - aqueous consistency with larger amount of water, with fecal content adhered to the perineum and tail, 3 - liquid with fecal content adhered to the perineum and tail. Calves with a 0 or 1 score are considered without diarrhea, while animals with a score 2 or 3 have diarrhea.

The assessment of the presence of respiratory disease was performed according to the procedures described by Poulsen \& McGuirk (2009). Scores from 0 to 3 were assigned according to intensity for rectal temperature, cough, nasal and ocular discharge, and ear position. Finally, the scores were added to obtain a final value. Calves whose sum of scores was $\geq 4$ were screened for the diagnosis of respiratory disease.

During all evaluations, the external umbilical region was evaluated by inspection and palpation for the detection of inflammatory signs such as redness, presence of purulent discharge, tenderness, increased 
umbilical volume, umbilical cord thickening, and abdominal tension (Figueiredo 1999).

Performance. To evaluate the impact of the use of antimicrobial on calf performance, the animals were weighed using calf weight tape. For this, the thoracic perimeter of an animal was measured, placing tape around the chest with the animal in season.

Collection and storage of samples. Stool samples were collected directly from the rectal ampoule with sterile latex gloves and packaged in sterile universal collectors. In the laboratory, stool samples were aliquoted into microtubes $(1.5 \mathrm{~mL})$ in the laminar flow in the presence of a Bunsen burner, and then stored in a freezer at $-80^{\circ} \mathrm{C}$ for Rotavirus and Coronavirus screening. The second aliquot of fresh feces, approximately 2 grams, was used in the diagnosis of Cryptosporidiosis by the sucrose saturated flotation technique. The remainder was frozen inside the freezer collection cups at $-20^{\circ} \mathrm{C}$ for later determination of the amount of dry matter in the feces. Blood samples were collected from calves by external jugular vein puncture, using a vacuum system, in tubes without anticoagulant $(10 \mathrm{~mL})$ and with anticoagulant Ethylenediaminetetraacetic Acid (EDTA). All samples were kept refrigerated between sample collection and transport to the laboratory.

Erythrogram. The hematological components belonging to the erythrogram were obtained by automatic system (BC 2800 Vet $^{\circledR}$ ).

Iron. Serum aliquots were thawed in the refrigerator (overnight), homogenized in an automatic homogenizer for further testing on an automated biochemical analyzer (Daytona Model, Randox Laboratories Ltd., Co. Antrium, UK). To measure iron concentration, a commercial kit (UIBC Iron, Randox ${ }^{\circledR}$, Cat. No. 357599) was used using the methodology described by the manufacturer.

Determination of dry stool matter. Correctly identified metal pots were used for weighing about 5 grams of feces on a high precision analytical balance. After weighing, the samples were transferred to a greenhouse at $103^{\circ} \mathrm{C}$, where they remained for 24 hours. After this period, the samples were removed from the greenhouse and transferred to the desiccator for 30 minutes to cool. The already cooled samples were weighed, and calculations were performed to determine the sample dry matter percentage (\% Dry matter $=$ [dry sample mass/wet sample mass] $\mathrm{x} 100)$. Cases of diarrhea were considered as feces containing a percentage of $\leq 15 \%$ of dry matter (Dirksen et al. 1993).

Detection of Cryptosporidium. The detection of Cryptosporidium spp. was performed by the sucrose saturated flotation technique in stool samples with scores 2 and 3. To do so, initially, the feces were washed to remove the fat and facilitate the observation of protozoa. One to two grams of feces were added to a collecting beaker with 8 to $9 \mathrm{~mL}$ of distilled water; with the aid of a glass stick, the feces were utterly diluted. The solution was sieved, and the liquid fraction added into a $15 \mathrm{~mL}$ plastic tube, then $4 \mathrm{~mL}$ of ether was added to the tube and then homogenized. Samples were centrifuged for five minutes at $796 \mathrm{x}$ g. After this process, the fat layer and the supernatant were removed with the aid of a Pasteur pipette, and the walls of the plastic tube were wiped with gauze. The stool "pellet" was added in $9 \mathrm{~mL}$ saturated sucrose solution and homogenized and centrifuged for ten minutes at $264 \mathrm{xg}$ (Ogassawara \& Benassi 1980). The supernatant was removed with a metal handle and placed on a glass slide, covered with a coverslip, and observed under a 400X magnification optical microscope.

Multiplex semi-nested RT-PCR for detection of group coronavirus and rotavirus A. Fecal score 2 and 3 samples were screened for detection of Rotavirus and Coronavirus by the system multiplex semi-nested RT-PCR, according to the technique described by Asano et al. (2010). Fecal samples were first prepared as $50 \%$ (liquid stool) or $20 \%$ (pasty stool) suspensions in DEPC-water (Diethylpyrocarbonate) and clarified at 5,000 x g/15min at $4^{\circ} \mathrm{C}$, taking the supernatant as a sample.

Total RNA extraction from the fecal sample suspensions was performed with TRIzolReagent ${ }^{\mathrm{TM}}$ (Invitrogen, Carlsbad/CA, USA), according to the manufacturer's instructions. Kakegawa (Akashi et al. 1980) and 8209 (Rodriguez et al. 2004) strains were used as positive controls for bovine coronavirus $(\mathrm{BCoV})$ and rotavirus, respectively, and water-DEPC as negative control.

For the detection of $\mathrm{BCoV}$, A set of three primers directed to the BCoV N-nucleocapsid protein-coding gene was used. The RT-PCR reactions for rotavirus detection were performed using three primers directed to the viral protein-coding gene VP1 (Table 1).

Each RNA-containing tube was brought to $95^{\circ} \mathrm{C}$ for 5 minutes for RNA denaturation, then immersed in ice and added from the 1x FirstStrand Buffer ${ }^{\circledast}, 1 \mathrm{mM}$ of each dNTP, $10 \mathrm{mM}$ reverse transcription combination reagent DTT, $1 \mu \mathrm{M}$ of each primer (BCOV1 + BCOV2 for BCoV, ROT1 + ROT2 for rotavirus) and 400U M-MLV Reverse Transcriptase $^{\circledR}$ (Invitrogen ${ }^{\circledR}$ ) for a final volume of $40 \mu \mathrm{L}$, reverse transcribed at $42^{\circ} \mathrm{C} / 60$ minutes.

After obtaining the complementary DNA, the PCR reaction was performed in a thermal cycler. To this end, $2.5 \mu \mathrm{L}$ of the respective cDNA was added to the PCR reagent combination containing $1 \mathrm{x}$ PCR Buffer $^{\circledR}$ (Invitrogen ${ }^{\circledR}$ ), $0.2 \mathrm{mM}$ from each dNTP, $0.25 \mu \mathrm{M}$ from each pair of primers (BCOV1 + BCOV2 and BCOV1 + BCOV3 for BCoV, ROT1 + ROT2 and ROT1 + ROT3 for), $1.5 \mathrm{mMMgCl} 2$ and $0.5 \mathrm{U}$ Platinum Taq DNA Polymerase ${ }^{\circledR}\left(\right.$ Invitrogen $^{\circledR}$ ) to a final volume of $25 \mu \mathrm{L}$ supplemented with DEPC-water.

The tubes were then brought to the thermal cycler for initial denaturation at $94^{\circ} \mathrm{C} / 4 \mathrm{~min}$, followed by 35 cycles of $94^{\circ} \mathrm{C} / 30 \mathrm{sec}$ (denaturation), $55^{\circ} \mathrm{C} / 30 \mathrm{sec}$ with gradient $5^{\circ} \mathrm{C}$ (hybridization) and $72^{\circ} \mathrm{C} / 45 \mathrm{sec}$ (polymerization), followed by the cycle, $72^{\circ} \mathrm{C} / 5 \mathrm{~min}$

Table 1. Primers used for the detection of bovine coronavirus $\mathrm{N}$-nucleocapsid protein-coding gene and its hybridizing nucleotide regions in the Mebus sample $\mathrm{N}$ gene (U00735), primers used for the detection of rotavirus VP1 viral protein-coding gene group A and nucleotide regions hybridizing to genomic segment 1 of sample KJ44 (DQ494405.1), fusion temperatures (Tm) and their amplicons (in base pairs); and nucleotide regions hybridizing to accession sequence GenBank NC_006853, melting temperatures (Tm) and their amplicon (in base pairs)

\begin{tabular}{lllcrr}
\hline \multicolumn{1}{c}{ Target } & \multicolumn{1}{c}{ Primer } & \multicolumn{1}{c}{ Sequence (5'-3') } & Region & Tm & Amplicon \\
\hline Coronavirus & BCOV1 (sense) & AAGAGCTCAAYCCAAGCAAACTGY & $123-146$ & $60^{\circ} \mathrm{C}$ & $463 \mathrm{pb}$ \\
& BCOV2 (antisense) & AGCAGACCTTCCTGAGCCTTCAAT & $562-585$ & $60^{\circ} \mathrm{C}$ & $463 \mathrm{pb}$ \\
& BCOV3 (antisense) & TCAATRTCGGTGCCATACTGGTCT & $405-428$ & $59.9^{\circ} \mathrm{C}$ & $306 \mathrm{pb}$ (with BCOV1) \\
& & & & & \\
Rotavirus & ROT1 (sense) & CTCTGGCAAARCTGGTGTCA & $737-753$ & $59.7^{\circ} \mathrm{C}$ & $492 \mathrm{pb}$ \\
& ROT2 (antisense) & CATTCGACGCTGATGACATY & $1206-1225$ & $59.7^{\circ} \mathrm{C}$ & $492 \mathrm{pb}$ \\
& ROT3 (antisense) & ARCAATCRACCAACCASTCCTGTA & $938-961$ & $598^{\circ} \mathrm{C}$ & $228 \mathrm{pb}($ with ROT1)
\end{tabular}


for the final extension. After electrophoresis on $1.5 \%$, agarose gel stained with $0.5 \mu \mathrm{g} / \mathrm{mL}$ ethidium bromide and observed under ultraviolet light.

The hemi-nested PCR for BCoV and rotavirus was performed by adding $2.5 \mu \mathrm{L}$ of the first amplification product to the PCR reagent combination containing $1 \mathrm{x}$ PCR Buffer ${ }^{\circledR}$ (Invitrogen ${ }^{\circledR}$ ), $0.2 \mathrm{mM}$ from each dNTP, $0.25 \mu \mathrm{M}$ of each primer (BCOV1 + BCOV3 for BCoV, ROT1 + ROT3 for rotavirus), $1.5 \mathrm{mMMgCl} 2$ and $0.5 \mathrm{U}$ Platinum Taq DNA Polymerase ${ }^{\circledR}$ (Invitrogen ${ }^{\circledR}$ ) and sterile ultrapure water (to a final volume of $25 \mu \mathrm{L}$ ), leading to the thermal cycler initial denaturation of $94^{\circ} \mathrm{C} / 4 \mathrm{~min}$ followed by 25 cycles of $94^{\circ} \mathrm{C} / 30 \mathrm{sec}$ (denaturation), $55^{\circ} \mathrm{C} / 30 \mathrm{sec}$ with gradient of $5^{\circ} \mathrm{C}$ (hybridization) and $72^{\circ} \mathrm{C} / 45 \mathrm{sec}$ (polymerization) followed by $72^{\circ} \mathrm{C} / 5 \mathrm{~min}$ for the final extension. After electrophoresis on $1.5 \%$, agarose gel stained with $0.5 \mu \mathrm{g} / \mathrm{mL}$ ethidium bromide and observed under ultraviolet light.

Statistical analysis. Statistical analysis was performed using the SPSS 19.0 statistical program (IBM Corp. Released 2011, IBM SPSS Statistics for Windows, Version 19.0, Armonk/NY).

Variables with quantitative values were evaluated for distribution concerning the Gaussian curve by the Shapiro-Wilk test. Data that did not present normal distribution were submitted to $\log _{10}$, square root, or inverse transformation to verify the possibility of performing a parametric analysis. Mean and standard deviation measurements represent parametric data. Student's t-test for independent samples was used to compare the values obtained in the group ATB- and group ATB+ in every moment. Time analysis was assessed by one-way ANOVA calculations for repeated time measurements within the same group with Tukey post hoc test. In the case where the transformations occurred, the $p$ presented in the tables refers to the tests related to the transformed values, while the described values are real. The nonparametric variables were represented by the median, quartile range, minimum and maximum values; the comparison between groups was performed by the Mann-Whitney test. Qualitative data (scores and presence of diseases) were presented in absolute values and frequencies, and the Chi-square test performed the comparison between groups. The analyzes were considered significant when $\mathrm{P} \leq 0.05\left(^{*}\right)$.

\section{RESULTS}

This study evaluated the influence of prophylactic use of tulathromycin provided up to 12 hours after birth on the performance and health of calves in the neonatal period through clinical evaluation, disease score, weight gain, and diarrhea diagnosis.

\section{Clinical evaluation}

Mean values and standard deviation for vital functions, weight gain, and frequency of changes in mucosal color are shown in Figure 1.

Heart rate was higher in ATB+ group $(156.9 \pm 23.9 \mathrm{bpm})$ compared to ATB- $(138.2 \pm 13.6 \mathrm{bpm})$ in the first assessment
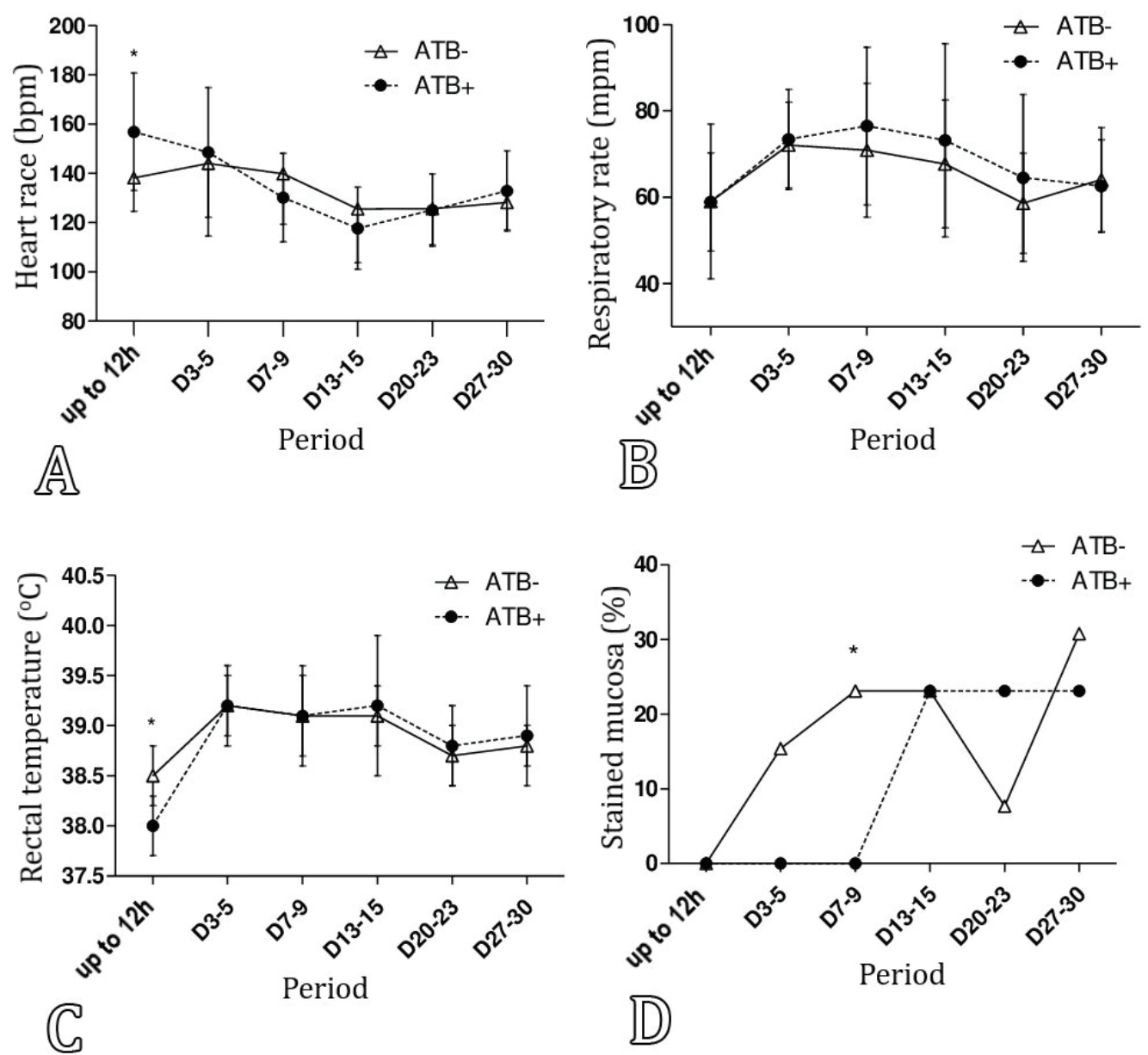

Fig.1. Mean values and standard deviation for (A) heart rate, $(\mathbf{B})$ respiratory rate, $(\mathbf{C})$ rectal temperature and (D) percentage of stained mucosa in ATB- and ATB+ Holstein calves in the first month of life. 
performed in the first 12 hours of life $(\mathrm{P}=0.022)$ (Fig.1A). In general, time analysis detected a decrease in heart rate from $\leq 12 \mathrm{~h}$ to $\mathrm{D} 13-15$ in ATB+ group $(\mathrm{P}=0.000)$. Respiratory rate was similar between groups at one month of life $(\mathrm{P} \geq 0.358)$ (Fig.1B). The respiratory rate in ATB- group increased from $\leq 12 \mathrm{~h}$ to D3-5. After this period, there was a progressive decrease from D3-5 to D20-23 and an increase in D27-30 $(\mathrm{P}=0.047)$. In $\mathrm{ATB}+$ group, there was an increase in respiratory movements from $\leq 12 \mathrm{~h}$ to $\mathrm{D} 7-9$, with a progressive decrease until D27-30 ( $\mathrm{P}=0.048)$.

The $\mathrm{T}^{\circ} \mathrm{C}$ of the calves was higher in ATB- group $\left(38.5 \pm 0.3^{\circ} \mathrm{C}\right)$ about the ATB $+\left(38.0 \pm 0.3^{\circ} \mathrm{C}\right)$ in the first evaluation moment $(\leq 12 \mathrm{~h}$ of life) $(\mathrm{P}=0.002)$. (Fig.1C). In general, time analysis revealed an increase in $\mathrm{T}^{\circ} \mathrm{C}$ from $\leq 12 \mathrm{~h}$ to D3-5 in both groups, with a decrease in values in ATB+ group at subsequent times $(\mathrm{P}=0.000)$. $\mathrm{T}^{\circ} \mathrm{C}$ was more oscillating from $\mathrm{D} 3-5$ in ATB- group, with an increase in values from D3-5 to D13-15 with a slight decrease in D20-23 and D27-D30 ( $\mathrm{P}=0.000)$.
All calves in both groups were hydrated (dehydration $\leq 5 \%$ ) and presented Capillary Refill Time (CRT) $\leq 2.0$ at all times. The calves' mucous membranes of both experimental groups were rosy in the first evaluation performed between birth and 12 hours of life $(\leq 12 \mathrm{~h})$, but only the ATB- group presented hypocolored mucous membranes in D3-5 and D7-9 (Fig.1D)., most often from animals with hypocolored mucosa in ATB- group at time D7-9 (ATB- $=23.1 \%$; ATB $+=0.0 \%$ ). The ATB + calves began to show stained mucous from D13-15, but the frequencies between groups were similar from that moment.

\section{Erythrogram}

Mean values and standard deviations for erythrogram components are shown in Figure 2. The mean values of red blood cells were similar between the ATB- and ATB+ groups $(\mathrm{P} \geq 0.236)$ (Fig.2A). Mean hemoglobin values were similar between ATB- and ATB+ groups (Fig.2B). At D3-5, it could

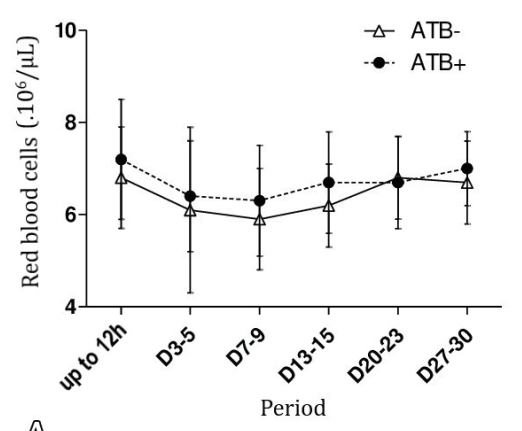

起

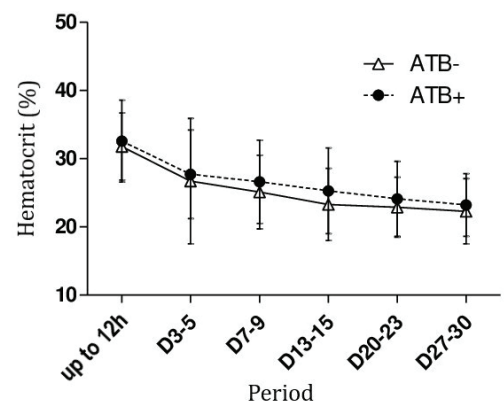

C

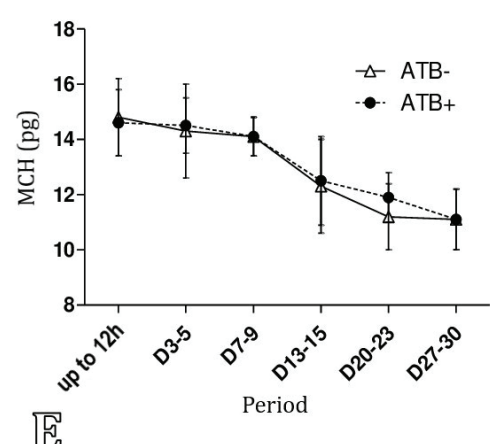

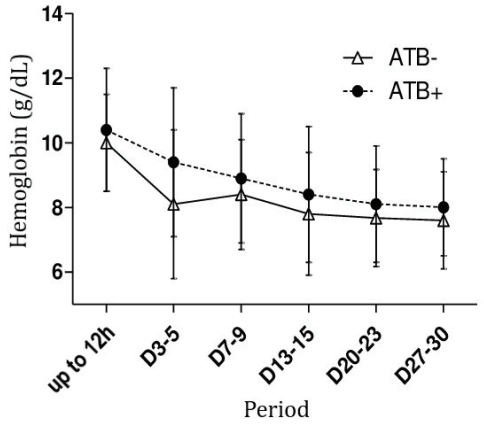

B

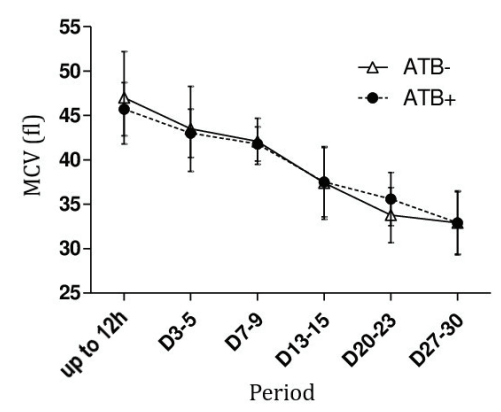

D)

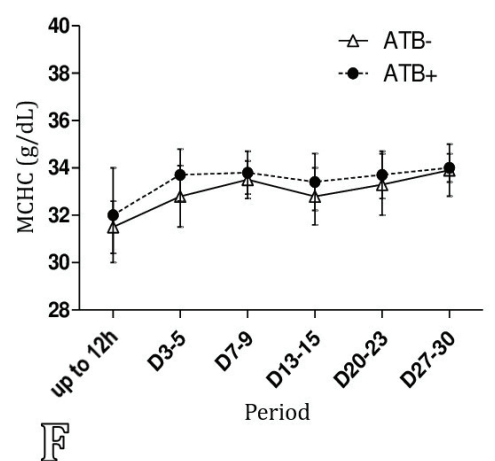

Fig.2. Mean values for (A) red blood cells (x106/ $\mu \mathrm{L}),(\mathbf{B})$ hemoglobin (g/dL), (C) hematocrit (\%), (D) Mean Corpuscular Volume (MCV) (fl), (E) Mean Corpuscular Hemoglobin (MCH) (pg) and (F) Mean Corpuscular Hemoglobin Concentration (MCHC (g/dL)) in ATB-and ATB+ Holstein calves in the first month of life. 
be observed higher hemoglobin values in calves receiving a tulathromycin dose at birth but without statistical difference $(\mathrm{P}=0.071)$. The time profile revealed a gradual decrease in hemoglobin levels in ATB+ $(\mathrm{P}=0.005)$ and ATB- $(\mathrm{P}=0.011)$ groups. The mean hematocrit values were similar between the ATB- and ATB+ groups ( $\mathrm{P} \geq 0.359)$ (Fig.2C), time analysis revealed a gradual decrease of the values in the first month of life in ATB+ $(\mathrm{P}=0.001)$ and ATB- groups $(\mathrm{P}=0.001)$.

It was not possible to observe differences in the comparison between groups for hematimetric indices (Fig.2F). Time analysis showed a progressive decrease in the mean values of Mean Corpuscular Volume (MCV) and Mean Corpuscular Hemoglobin (MCH) in both groups in the first month of life (Figs.2D,E). The mean values of Mean Corpuscular Hemoglobin Concentration (MCHC) also presented time variations in $\mathrm{ATB}+(\mathrm{P}=0.001)$ and ATB- $(\mathrm{P}=0.000)$ groups, with a gradual increase in the values from 12 hours after birth to D27-30 in both experimental groups.

The anemia frequencies in ATB + and ATB- groups are shown in figure 3 . Individual evaluation of erythrograms at different times was performed to detect anemia, according to the reference values established by Brun-Hansen et al. (2006). The frequency of anemia was higher in the ATB- group $(61.5 \%)$ than the ATB+ $(15.4 \%)$ in $\mathrm{D} 3-5(\mathrm{P}=0.016)$, showing statistical difference.

\section{Iron}

The mean values and standard deviation of serum iron concentration for ATB- and ATB+ calves are shown in Figure 4. There was no difference between groups in mean iron concentrations, despite the higher values in ATB+ compared to ATB- in D3-5 $(\mathrm{P}=0.051)$. The maximum iron peak for both groups was up to 12 hours after birth (ATB- $=14.43 \pm 8.82 \mu \mathrm{M} / \mathrm{L}, \mathrm{ATB}+=15.06 \pm 8.88 \mu \mathrm{M} / \mathrm{L})$, values up to D27-30 (ATB- $=3.9 \pm 2.01 \mu \mathrm{M} / \mathrm{L}, \mathrm{ATB}+=3.95 \pm 2.52 \mu \mathrm{M} / \mathrm{L})$ $(\mathrm{P}=0.000)$.

\section{Disease scores}

The diarrhea frequencies assessed by fecal score and dry matter, umbilical inflammation, and percentage of dry matter in calf feces are described in Figure 5 and 6.

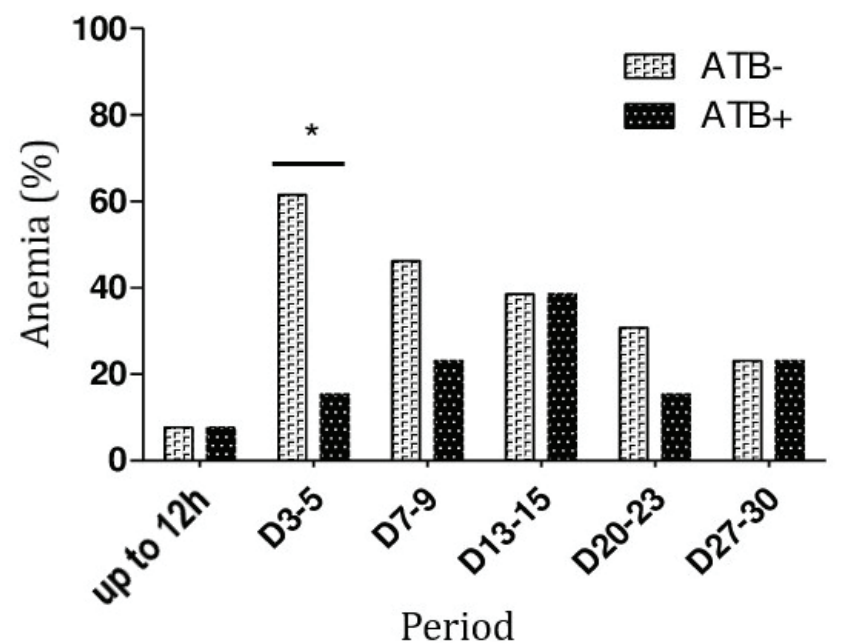

Fig.3. Frequency of Holstein calves presenting with anemia in ATB- and ATB+ groups in the first month of life.
Diarrhea started soon after breastfeeding at $\leq 12 \mathrm{~h}$, with a maximum prevalence between D13-15 (Fig.5A). Higher frequency of diarrhea was observed in ATB+ group through the fecal dry matter classification $(\mathrm{ATB}+=84.6 \%$, ATB- $=53.8 \%$ ) (Fig.5B). The frequency of diarrhea decreased at D20-23 (Score: $\mathrm{ATB}+=15.4 \%$, ATB- = 23.1\%; Dry Matter: $\mathrm{ATB}+=23.1 \%$, ATB- $=15.4 \%)$ and D27-30 (Score: $\mathrm{ATB}+=30.8 \%$, ATB- $=7.7 \%$; Dry Matter: ATB $+=30.8 \%$, ATB- $=15.4 \%$ ). Quantitative comparison of the percentage (\%) of dry matter in calf feces revealed differences between the groups, with a higher average in ATB- calves at birth $(\mathrm{P}=0.046)$. Moderate Spearman correlation ( $\mathrm{r}=0.633)$ was observed between detection of diarrhea by fecal score and percentage of dry matter $(\mathrm{P}=0.000)$.

Umbilical changes were detected at D3-5 (ATB- $=38.5$, $\mathrm{ATB}+=7.7 \%, \mathrm{P}=0.063), \mathrm{D} 7-9$ (ATB- = 23.1, $\mathrm{ATB}+=15.4 \%$, $\mathrm{P}=0.619$ ) and $\mathrm{D} 13-15$ (ATB- $=23.1, \mathrm{ATB}+=0.0 \%, \mathrm{P}=0.066$ ) (Fig.5C). In general, the ATB- group had a higher frequency of umbilical inflammation.

Thirteen cases of respiratory disease were detected during the study period, eight in ATB-group and five in ATB+ group (Fig.5D). D27-30 presented the highest frequency of bronchopneumonia, with $23.1 \%$ of the animals from the affected ATB- group and $7.7 \%$ of the animals from the $\mathrm{ATB}+$ group. No statistical difference was observed between the groups at any of the evaluated moments.

\section{Performance}

Daily weight gain was similar between experimental groups $(\mathrm{P} \geq 0.241)$ (Fig.7). Both groups showed weight gain above $1 \mathrm{~kg}$ in D3-5 and D7-9, but there was a marked reduction in weight gain in D13-15 in ATB+ $(0.4 \pm 0.2 \mathrm{~kg})$ and ATB- $(0.3 \pm 0.5 \mathrm{~kg})$, when it was observed the highest frequency of diarrhea in calves. After diarrhea peak (D13-15) the animals restored weight gain D20-23 (ATB- $=1.0 \pm 0.6 \mathrm{~kg}, \mathrm{ATB}+=0.7 \pm 0.4 \mathrm{~kg}$ ), D27-30 (ATB- $=1.0 \pm 0.5 \mathrm{~kg}, \mathrm{ATB}+=1.0 \pm 0.5 \mathrm{~kg}$ ).

\section{Diarrhea etiology}

The results obtained for the detection of Cryptosporidium spp. and rotavirus are shown in Figure 8. The dynamics of Cryptosporidium spp. were similar between experimental

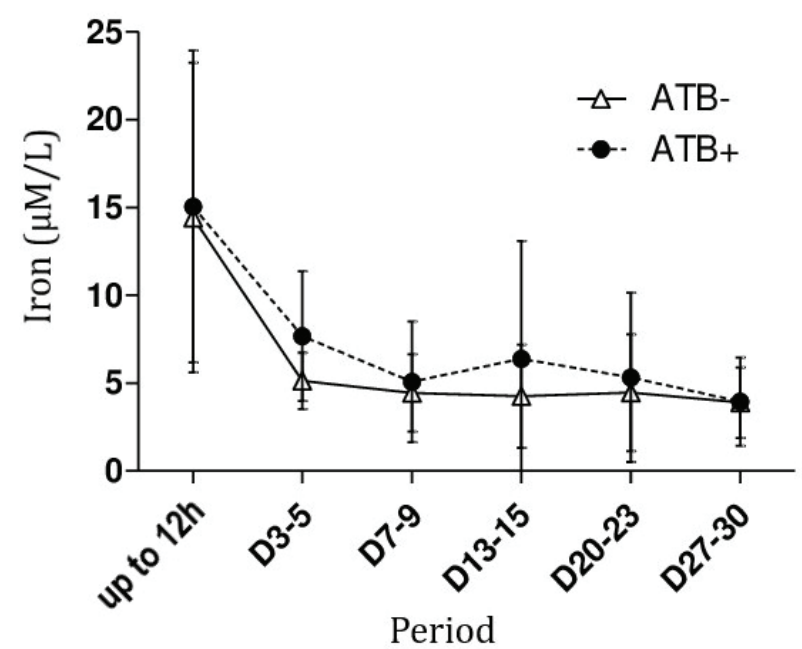

Fig.4. Mean iron values ( $\mu \mathrm{M} / \mathrm{L})$ in the serum of ATB- and ATB+ Holstein calves in the first month of life. 

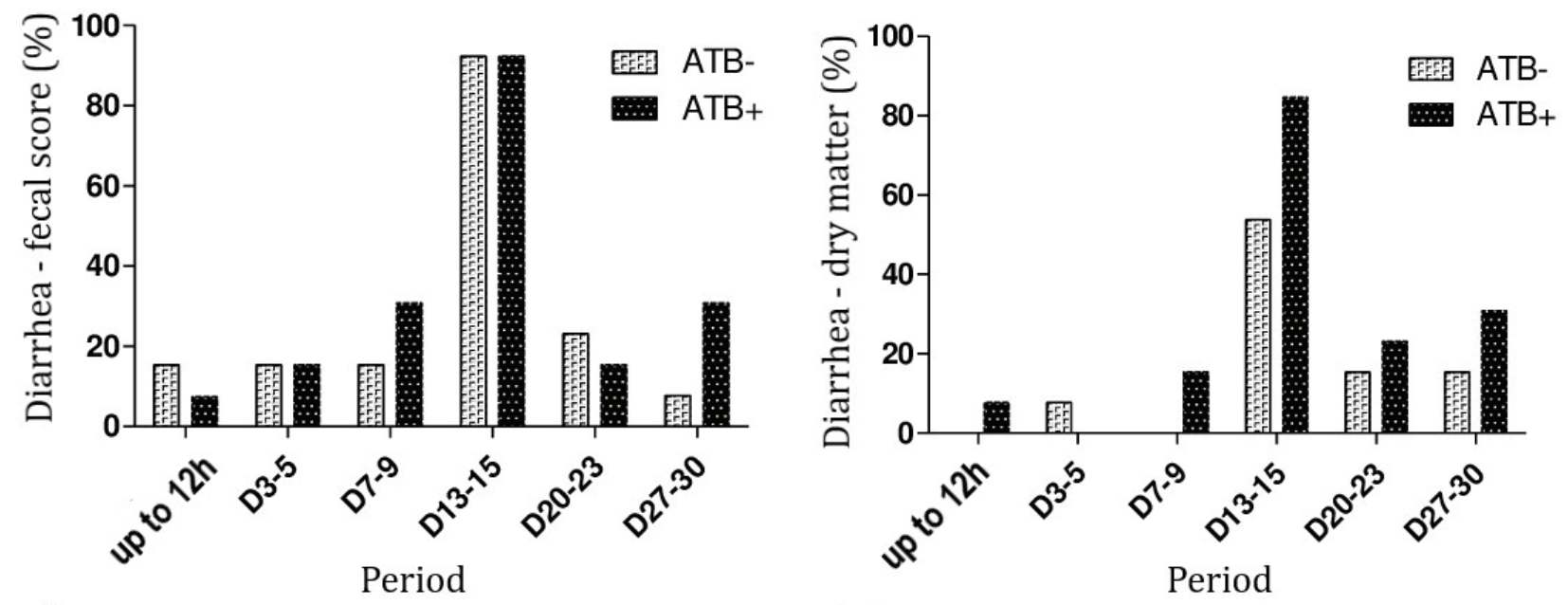

$\mathbb{A}$

B

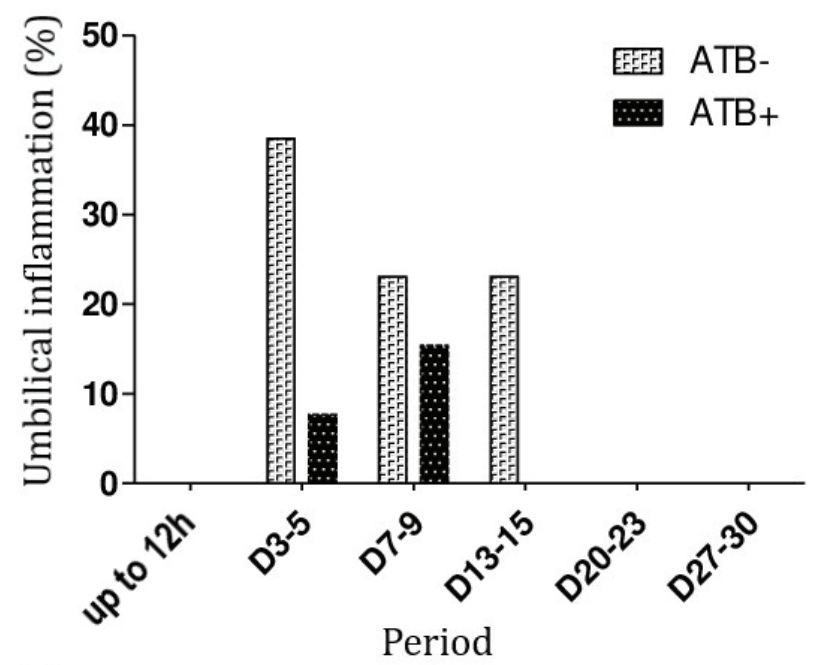

$G$

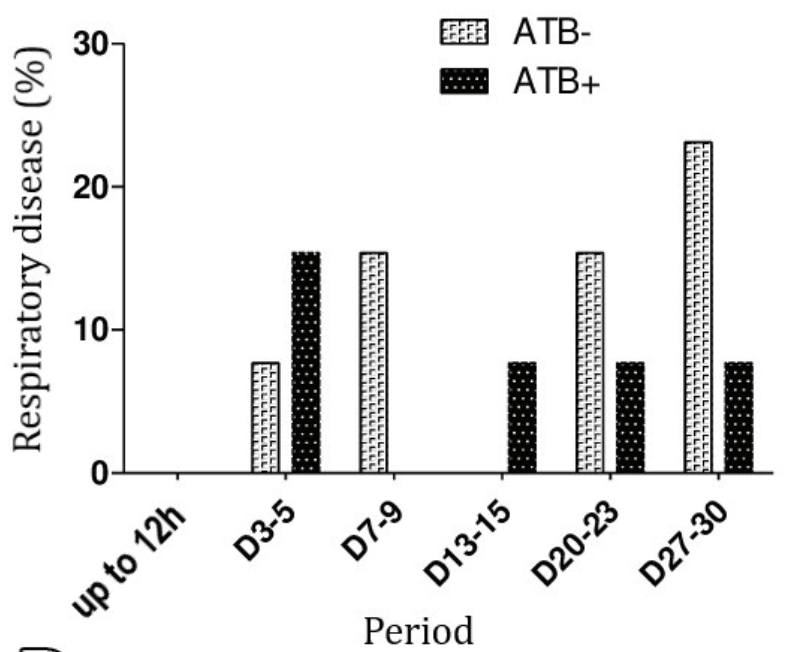

Fig.5. Frequency (\%) of Holstein ATB- and ATB+ Holstein calves presenting (A) diarrhea by fecal score evaluation, (B) diarrhea by fecal dry matter evaluation, (C) umbilical inflammation and (D) respiratory disease in the first month of life.

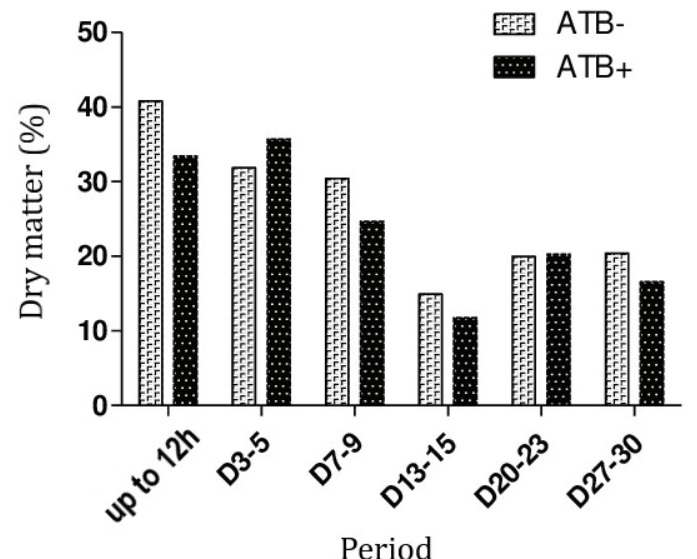

Fig.6. Mean values and standard deviations for the percentage of dry matter in feces of ATB- and ATB+ Holstein calves in the first month of life.

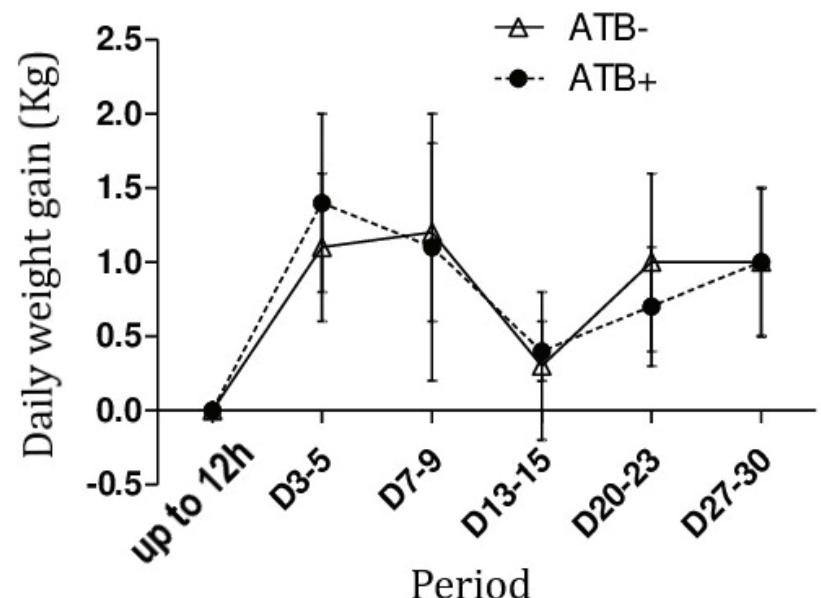

Fig.7. Daily Weight Gain (DWG) of ATB- and ATB+ Holstein calves groups in the first month of life. 

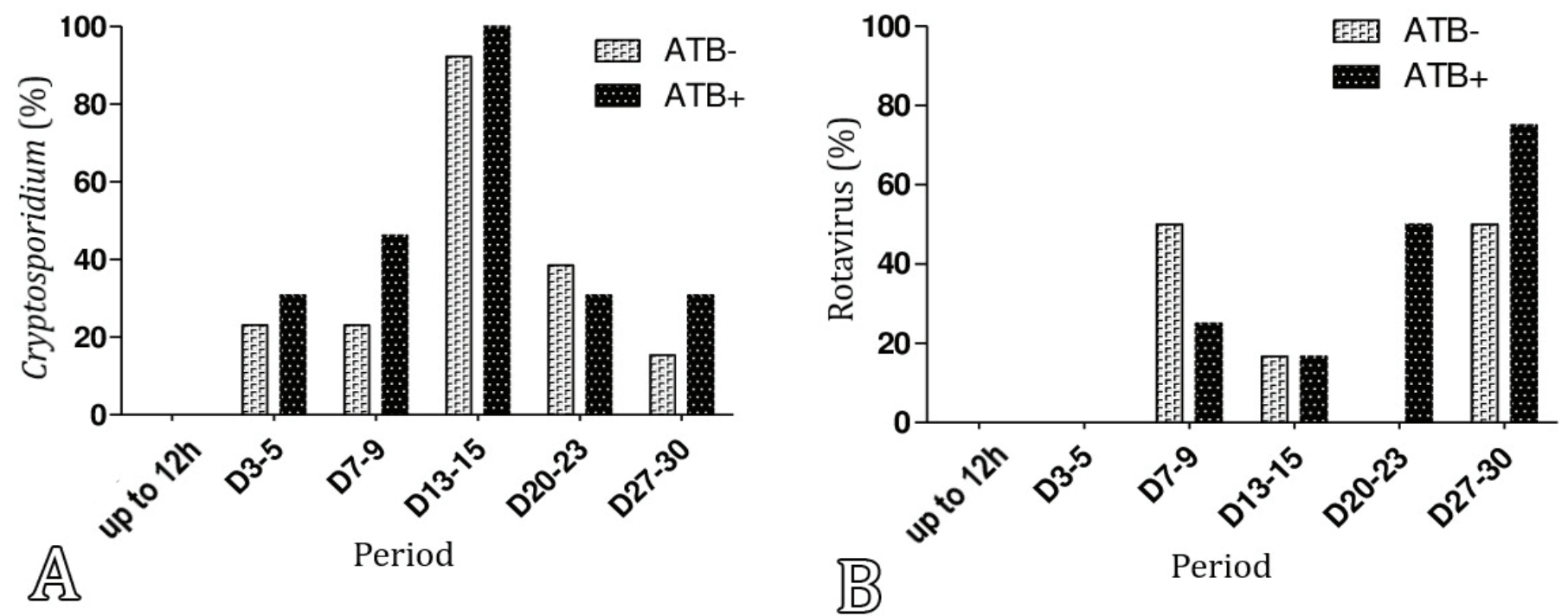

Fig.8. Frequency (\%) of (A) Cryptosporidium spp. and (B) rotavirus in the feces of Holstein calves presenting with diarrhea in ATB- and ATB+ groups in the first month of life.

groups from D3-5 to D27-30 (Fig.8A). At $\leq 12 \mathrm{~h}$, two calves with ATB- diarrhea and one calf with ATB+ diarrhea were observed, however this clinical manifestation was not caused by Cryptosporidium spp. In the subsequent time (from D3-5 to D20-23), all calves ATB+ and ATB- with diarrhea were positive for fecal Cryptosporidium spp. (100\%). In D27-30 frequencies of 100\% (1/1) and 75\% (3/4) for Cryptosporidium spp. were observed in ATB- and ATB+ groups, respectively.

The frequency of rotavirus in the fecal samples with a score of 2 or 3 was similar between groups and ATB- and ATB+ $(\mathrm{P} \geq 0.171$ ) (Fig.8B). Rotavirus positive tests were detected at D7-9 (ATB- $=50 \%, \mathrm{ATB}+=25 \%)$, D13-15 (ATB- $=16.7 \%$, $\mathrm{ATB}+=16.7 \%), \mathrm{D} 20-23(\mathrm{ATB}-=0 \%, \mathrm{ATB}+=50 \%)$ and $\mathrm{D} 27-30$ (ATB- $=50 \%, \mathrm{ATB}+=75 \%$ ). Coronaviruses were not detected in the feces score 2 and 3 of the calves of both groups.

\section{DISCUSSION}

The proposal for this study came initially with questions from farmers about the effectiveness of prophylactic treatment with calf antimicrobials. Thus, the objective of this study was to evaluate the influence of early use of antimicrobial (tulathromycin) on the health and performance of calves during the neonatal period.

Thus, it could not be observed statistical differences between the groups regarding the clinical examination resulting from the use of antimicrobial. The variations observed in the first evaluation reflect the adaptation of the calves to the extrauterine environment as a result of the interval between birth and first evaluation (Mee 2008). The heart rate profile throughout the study was similar to that found by Novo et al. (2017), who also observed a decrease in values up to 14 and 21 days and an increase in subsequent moments. Respiratory rate showed an increasing behavior in the first week of life with progressive reduction until D27-30, corroborating the findings of Silva et al. (2016). These variations in time reflect the physiological homeostatic variability during the neonatal period, as well as the incomplete development of the anatomical and functional functions of neonates. The temperature variation profile over time is within the physiological values for the species and agrees with Silva et al. (2016). After birth, calves need to activate thermogenic mechanisms for temperature control. This regulation depends on the environment in which this animal is housed, and the colostrum intake, and the temperature tends to stabilize within 48 and 72 hours (Leone et al. 2009).

Red blood cell analysis revealed lower hemoglobin and MCHC concentrations in D3-5 in ATB- group calves. These data are consistent with the lower iron content and higher frequency of stained mucosa and anemia in ATB- group. Low iron concentration in calves in the neonatal period is due to low iron concentration in milk. However, all calves used in this experiment received the same diet, and it could be observed lower iron levels in ATB- group. These data suggest the effect of chronic inflammatory processes arising from umbilical inflammation in ATB-group. Ganz (2005) states that this type of anemia may be a side effect of the host defense response to control bacterial multiplication, considering that iron is fundamental to its metabolism. The erythrogram showed classic variations over time due to age. Hemoglobin, hematocrit, MCV and MCH values decreased over time as described by Novo et al. (2015). Red blood cells decreased to the D7-9, progressively increasing from that time until the end of the experiment.

Umbilical inflammation was detected early between D3-5 to D13-15. Throughout this period, the disease was more frequent in ATB- calves. Affections related to the structures that constitute the umbilical cord are among the main factors affecting the development of newborns in the 1st week of life. We can suggest that the differences observed between the groups regarding the frequency of umbilical changes are due to the protection provided by the antimicrobial provided within the first 12 hours of life. Tulathromycin acts by inhibiting protein synthesis essential for bacterial metabolism; its action is highest against Gram-positive bacteria, especially during its 10-day period of action (Stanton et al. 2010, Ives \& Richeson 2015). Unfortunately we did not culture umbilical secretion to determine which microorganisms were responsible for 
inflammation in this region. However, we know that among the main agents involved in the etiology of umbilical infections are Staphylococcus spp., Streptococcus spp., Micrococcus spp., Bacillus spp., and Actinomyces pyogenes (Rengifo et al. 2006), which are Gram-positive bacteria and exhibit antimicrobial sensitivity used in this research.

The main disease which affected calves this experiment was diarrhea. Through the evaluation of the scores it can be observed that the diarrhea started soon after the colostrum breastfeeding at $\leq 12 \mathrm{~h}$, with maximum peak in D13-15, and frequency decrease in later moments. The frequency of diarrhea through the percentage of dry matter in the stool $(\leq 15 \%)$ was similar to that estimated by the scoring system. The average values of dry matter content presented lower percentage in the feces of ATB+ calves at moments D7-9 and D27-30, but without statistical difference.

Supplementation of oxytetracycline and neomycin antimicrobials in milk is the main route used to prevent diarrhea and increase calf weight gain. In general, research found null (Donovan et al. 2002) or unsatisfactory (Berge et al. 2009) effect with oral antimicrobial use, which agrees with the absence of positive results observed in this research for parenteral use of tulathromycin with the goal of decreasing the prevalence of diarrhea.

In our research, we observed a larger number of animals presenting diarrhea by evaluating the dry matter at time D13-15 for the ATB- group and we observed no effect on calves weight gain. Stanton et al. (2010) conducted research evaluating the effects of parenteral tulathromycin on disease occurrence and performance of calves and found different results from those found in our research. The authors found an $80 \%$ frequency of diarrhea in the treated group, while the control group had a rate of $87 \%$, corresponding to $1.8(\mathrm{P}=0.005)$ times more likely to have diarrhea. The weight gain of the calf group that received tulathromycin was $0.02 \pm 0.01 \mathrm{~kg} /$ day $(\mathrm{P}=0.010)$ higher than the control group animals.

The effect of prophylactic use of tulathromycin observed in this research did not show significant difference in relation to diarrhea, despite the higher frequency observed in ATB+ group, there were also no significant differences in animal performance. However, we must consider that the number of animals evaluated was small, which may have influenced this result, which is a limitation of this study. Thus, further research is needed to investigate the effect of antimicrobial on short and long term performance of calves, as well as its influence on intestinal microbiota.

Some mechanisms have been postulated in the association between diarrhea and antimicrobial use, such as: growth of opportunistic pathogens; changes in microbial metabolic functions; colonization by resistant bacteria and inability of microbiota to resist overgrowth of pathogenic microorganisms (McFarland 1999, Young \& Schmidt 2004). Changes in bacterial composition and quantity, even in the absence of overgrowth of pathogenic microorganisms, can lead to changes in colonic metabolism leading to diarrhea. Young \& Schmidt (2004) described that colonic bacteria, especially certain anaerobes, metabolize dietary carbohydrates and use them as an energy source to produce lactic acid and short chain fatty acids, the latter being absorbed by the colon. Loss of these bacteria due to antimicrobial treatment can lead to the accumulation of these carbohydrates that are not absorbed in the colon, leading to osmotic diarrhea, short chain fatty acids mainly butyrate is an important source of energy for the distal colon mucosa, reduced butyrate productions due to decreased anaerobic bacterial populations can cause direct mucosal functional disorders.

For the diagnosis of diarrhea, we performed the research of Cryptosporidium spp., rotavirus and coronavirus. A high frequency of ositive animals for Cryptosporidium spp. was observed, and the dynamics of infection were similar between experimental groups from D3-5 to D27-30. Regarding rotavirus, it was possible to identify 11 positive calves during the study period. Rotavirus positive tests were detected from D7-9 until the end of the study, in which higher frequency of rotavirus was observed in ATB+ group on D27-30, despite the absence of statistical differences. Coronaviruses were not detected in the feces score 2 and 3 of the calves of both groups. Several studies have shown that Cryptosporidium spp. associated or not with Rotavirus is the main agent involved in neonatal diarrhea, corroborating the findings of this research.

A study conducted in France with diarrhea dairy calves showed that only $6.1 \%$ of the animals studied were infected by $E$. coli $\mathrm{K} 99,14.3 \%$ by rotavirus, $6.8 \%$ by coronavirus, $0.3 \%$ by Salmonella spp. and $50 \%$ were excreting Cryptosporidium parvum oocysts. The peak of oocyst elimination reported in this study was on the seventh day of life (Naciri et al. 1999), different from what we observed in our study with higher prevalence in D13-15.

Despite Salmonella spp. being among the main causative agents of diarrhea we did not perform research on this agent. Previous work by this team in São Paulo found only two positive animals for Salmonella enteritidis on the second day of life. Due to the low frequency of this agent in São Paulo, associated with the need for specific means of collection and transportation of stools for a reliable diagnosis, is decided not to search this agent in this work. However, a study conducted in the state of Minas Gerais showed high frequencies (50 to 66\%) of Salmonella spp. in calves during lactation (Carvalho et al. 2014), which differs from the results found in other studies (Costa et al. 1979, Langoni et al. 2004, Ferreira et al. 2009). This finding may be associated with the type of rearing animals were submitted to, with high stocking rate, high humidity, organic matter accumulation, high temperature and age difference between the animals used in the different researches. Other studies also report the importance of Salmonella spp. in public health, salmonellosis being one of the leading causes of intestinal infections in humans (Pelkonen et al. 1994). Thus, we know that the lack of diarrhea diagnosis by Salmonella spp. is a limitation of this study.

At $\leq 12 \mathrm{~h}$ there were two calves with diarrhea in ATB- group and one calf with diarrhea in ATB+ group, however this clinical manifestation was not associated with Cryptosporidium spp. or to the rotavirus. Enterotoxigenic E. coli infections usually occur in animals less than five days old, so this bacterial group may have participated in the development of diarrhea observed in calves. Most strains of E. coli present in the gastrointestinal tract are non-pathogenic commensals and participate in the normal process of colonization of the intestine (Manzoor et al. 2015, El-Seedy et al. 2016). Unfortunately we did not perform E. coli research and identify virulence factors or search for genes that encode toxins (Andrade et al. 2012, Costa et al. 2014). Thus, we can suggest that the diarrhea observed in 
these animals at the very first moment of collection may have occurred due to the laxative effect of colostrum responsible for clearing the intestine through the elimination of meconium (Embrapa 2005).

Cows from this farm were vaccinated in the pre-partum period for E. coli, rotavirus and coronavirus, the low rate of rotavirus positive animals and absence of coronavirus may indirectly indicate the prevention of infection by passive antibody transfer by colostrum ingestion. It is worth noting that there are some differences regarding the effectiveness of vaccines used against agents that cause diarrhea. Meganck et al. (2015) reported that the quality of colostrum may reflect the success of the vaccination protocol. Many risk factors are associated with diarrhea, and identification of the etiological agent is important. Bartels et al. (2010) reported that the main risk factors for the presence of Cryptosporidium spp. were mixed infections; the presence of rotavirus in the feces increased the chances of detection of C. parvum by 2.2 times. Farms where calves with diarrhea were routinely treated with antimicrobials (orally or injected) were 3.2 times more likely to detect $C$. parvum.

The farm used for this research has excellent sanitary management and has protocols directed to cleaning and disinfecting the calf. The calves remained in individual cages with slatted wooden floors with a replaced hay bed once a day. Twice a week, all cages were sprayed with the chlorhexidine-cetrimide solution. After weaning, the stalls were washed with water, and after drying, fire, brooms, and lime were used. The stalls remained empty for about 30 days depending on the number of births despite proper sanitary management, a high frequency of Cryptosporidium spp. infection was observed, possibly because the product used in disinfection (chlorhexidine-cetrimide) has no action against this agent, despite its broad spectrum for bacteria, fungi, algae, and viruses.

Based on the data obtained in this research, it was possible to verify that the early use of antimicrobials near birth did not bring benefits about the prevalence of neonatal diarrhea, because it has no direct action on Cryptosporidium spp. and rotavirus. Thus, the establishment of etiological diagnosis is fundamental for definition therapeutic and prophylactic protocols with or without the use of antimicrobials. The cost of prophylactic treatment using one dose of tulathromycin (price of medication and application costs), not counting the work of collaborators, is around $\mathrm{R} \$ 7,50$ (reais) per animal. The cost and benefit of using this prophylactic protocol are unlikely to compensate financially as no improvement in diarrhea performance or prevalence could be observed. The only benefit detected was the decreased frequency of anemia and umbilical inflammation; however, these infections were mild, transient, and did not compromise the development of the animals.

\section{CONCLUSION}

The administration of prophylactic tulathromycin $(2.5 \mathrm{mg} / \mathrm{kg})$ at birth decreased the frequency of anemia in calves receiving the antimicrobial. This practice did not influence calf weight gain and diarrhea rates.

Conflict of interest statement.- The authors have no conflicts of interest to declare.

\section{REFERENCES}

Akashi H., Inaba Y., Miura Y., Tokuhisha S., Sato K. \& Satoda K. 1980. Properties of a coronavirus isolated from a cow with epizootic diarrhea. Vet. Microbiol. 5(4):265-276. <http://dx.doi.org/10.1016/0378-1135(80)90025-5>

Andrade G.I., Coura F.M., Santos E.L., Ferreira M.G., Galinari G.C., Facury Filho E.J., de Carvalho A.U., Lage A.P. \& Heinemann M.B. 2012. Identification of virulence factors by multiplex PCR in Escherichia coli isolated from calves in Minas Gerais, Brazil. Trop. Anim. Health Prod. 44(7):1783-1790. <http:// dx.doi.org/10.1007/s11250-012-0139-8><PMid:22476791>

Asano K.M., De Souza S.P., De Barros I.N., Ayres G.R., Silva S.O.S., Richtzenhain L.J. \& Brandão P.E. 2010. Multiplex semi-nested RT-PCR with exogenous internal control for simultaneous detection of bovine coronavirus and group A rotavirus. J. Virol. Methods 169(2):375-379. <http://dx.doi. org/10.1016/j.jviromet.2010.08.008> <PMid:20723564>

Aziz Q., Doré J., Emmanuel A., Guarner F. \& Quigley E.M.M. 2013. Gut microbiota and gastrointestinal health: current concepts and future directions. J. Neurogastroenterol. Motil. 25(1):4-15. <http://dx.doi.org/10.1111/ nmo.12046><PMid:23279728>

Barrington G.M. \& Parish S.M. 2001. Bovine neonatal immunology. Vet. Clin. N. Am. Food Anim. Pract. 17(3):463-476. <http://dx.doi.org/10.1016/ S0749-0720(15)30001-3><PMid:11692503>

Bartels C.J., Holzhauer M., Jorritsma R., Swart W.A. \& Lam T.J. 2010. Prevalence, prediction and risk factors of enteropathogens in normal and non-normal faeces of young Dutch dairy calves. Prev. Vet. Med. 93(2):162-169. <http:// dx.doi.org/10.1016/j.prevetmed.2009.09.020> <PMid:19819574>

Berge A.C.B., Moore D.A., Besser T.E. \& Sischo W.M. 2009. Targeting therapy to minimize antimicrobial use in preweaned calves: Effects on health growth, and treatment costs. J. Dairy Sci. 92(9):4707-4714. <http://dx.doi. org/10.3168/jds.2009-2199><PMid:19700735>

Brun-Hansen H.C., Kampen A.H. \& Lund A. 2006. Hematologic values in calves during the first 6 months of life. Vet. Clin. Pathol. 35(2):182-187. <http:// dx.doi.org/10.1111/j.1939-165X.2006.tb00111.x> <PMid:16783710>

Carvalho J.G., Carvalho A.U., Heinemann M.B., Coelho S.G., Paes P.R.O., Moreira G.H.F.A., Vespasiano L.C. \& Facury Filho E.J. 2014. Estudo longitudinal da infecção por enteropatógenos em bezerros neonatos, com diarreia, sob diferentes estratégias de aleitamento. Pesq Vet Bras. 34(6):529-553. <http://dx.doi.org/10.1590/S0100-736X2014000600006>

Chase C.C.L., Hurley D.J. \& Reber A.J. 2008. Neonatal immune development in the calf and its impact on vaccine response. Vet. Clin. N. Am. Food Anim Pract. 24(1):87-104. <http://dx.doi.org/10.1016/j.cvfa.2007.11.001> <PMid:18299033>

Costa R.R., Santos E.E., Andrade M.A., Torres A.J.A., Ribeiro A.R. \& Carneiro J.B 1979. Frequência e causas de doenças do aparelho digestivo em bezerros na bacia leiteira de Goiânia. Pesq. Agropec. Trop. 9:108-125.

Costa K., Alzamora Filho F., Costa J.N., Amorim C.R.N., Yano T. \& Conceição R.A. 2014. Fatores de virulência das amostras de Escherichia coli isoladas de bezerros com diarréia na região de Feira de Santana, Bahia. Revta Bras. Med. Vet. 36(4):430-436.

Dirksen G., Gründer H.D. \& Stöber M.R. 1993. Exame Clínico dos Bovinos Guanabara Koogan, Rio de Janeiro. 448p.

Donovan D.C., Franklin S.T., Chase C.C.L. \& Hippen A.R. 2002. Growth and health of Holstein calves fed milk replacers supplemented with antibiotics or enteroguard. J. Dairy Sci. 85(4):947-950. <http://dx.doi.org/10.3168/ jds.S0022-0302(02)74153-2><PMid:12018440>

El-Seedy F.R., Abed A.H., Yanni H.A. \& El-Rahman S.A. 2016. Prevalence of Salmonella and E. coli in neonatal diarrheic calves. Beni-Seuf Univ. J. Appl. Sci. 5(1):45-51.

Embrapa 2005. Criação de bezerras em sistemas de produção de leite Circular Técnica no 38, Aracaju, SE. 8p.

Feitosa F.L.F. 2014. Semiologia Veterinária: a arte do diagnóstico. 3aㅡ ed. Roca, São Paulo. 644p.

Fernández L., Langa S., Martín V., Maldonado A., Jiménez E., Martín R. \& Rodríguez J.M. 2013. The human milk microbiota: origin and potential 
roles in health and disease. Pharmacol. Res. 69(1):1-10. <http://dx.doi. org/10.1016/j.phrs.2012.09.001> <PMid:22974824>

Ferreira M.G., Facury Filho E.J., Heinemann M.B., Carvalho A.U., Lage A.P., Ferreira P.M. \& Freitas M.D. 2009. Prevalência de Eimeria, helmintos, Escherichia coli, Salmonella, Rotavirus, Coronavirus e Cryptosporidium parvum em propriedades leiteiras de Minas Gerais. Ciênc. Anim. Bras. 1:524-529.

Figueiredo L.J.C. 1999. Onfalopatias de Bezerros. EDUFBA, Salvador. 94p.

Gabler M.T., Tozer P.R. \& Heinrichs A.J. 2000. Development of a cost analysis spreadsheet for calculating the costs to raise a replacement dairy heifer. J. Dairy Sci. 83(5):1104-1109. <http://dx.doi.org/10.3168/jds.S00220302(00)74975-7><PMid:10821586>

Ganz T. 2005. Hepcidin: a regulator of intestinal iron absorption and iron recycling by macrophages. Best Pract. Res., Clin. Haematol. 18(2):171-182. <http://dx.doi.org/10.1016/j.beha.2004.08.020 > <PMid:15737883>

Gomez D.E., Arroyo L.G., Costa M.C., Viel L. \& Weese J.S. 2017. Characterization of the fecal bacterial microbiota of healthy and diarrheic dairy calves. J. Vet. Intern. Med.31(3):928-939. <http://dx.doi.org/10.1111/jvim.14695> $<$ PMid:28390070>

Heinrichs A.J. \& Heinrichs B.S. 2011. A prospective study of calf factors affecting first-lactation and lifetime milk production and age of cows when removed from the herd. J. Dairy Sci. 94(1):336-341. <http://dx.doi. org/10.3168/jds.2010-3170><PMid:21183043>

Heinrichs A.J., Heinrichs B.S., Harel O., Rogers G.W. \& Place N.T. 2005. A prospective study of calf factors affecting age, body size, and body condition score at first calving of Holstein dairy heifers. J. Dairy Sci. 88(8):2828-2835. <http://dx.doi.org/10.3168/jds.S0022-0302(05)72963-5><PMid:16027197>

Ives S.E. \& Richeson J.T. 2015. Use of antimicrobial metaphylaxis for the control of bovine respiratory disease in high-risk cattle. Vet. Clin. N. Am. Food Anim. Pract. 31(3):341-350, v. <http://dx.doi.org/10.1016/j. cvfa.2015.05.008><PMid:26227871>

Kaneene J.B., Warnick L.D., Bolin C.A., Erskine R.J., May K. \& Miller R. 2008. Changes in tetracycline susceptibility of enteric bacteria following switching to nonmedicated milk replacer for dairy calves. . J. Clin. Microbiol. 46(6):19681977. <http://dx.doi.org/10.1128/JCM.00169-08> <PMid:18417664>

Langoni H., Linhares A.C., Avila F.A., Silva A.V. \& Elias A.0. 2004. Contribuição ao estudo da etiologia das diarreias em bezerros de aptidão leiteira no Estado de São Paulo, Brasil. Braz. J. Vet. Res. Anim. Sci. 41:313-319.

Leone R.A.B., Matsuno R.M.J., Veronezi A.H.M. \& Pereira D.M. 2009. Neonatologia de grandes animais. Revta Ciênc. Eletrôn. Med. Vet. 12:1-8.

Manzoor R., Shah M.I., Ul-husna A., Wani S.A., Pandit F., Dar P.A. \& Mir M.I. 2015. Prevalence, serodiversity and antibiogram of enterotoxigenic Escherichia coli (ETEC) in diarrhoeic calves and lambs of Kashmir valley (J\&K), India. IJANS 7(1):477-481. <http://dx.doi.org/10.31018/jans.v7i1.635>

McFarland L.V. 1999. Epidemiology, risk factors and treatments for antibiotic-associated diarrhea. J. Dig. Dis. 16(5):292-307.<http://dx.doi. org/10.1159/000016879><PMid:9892789>

McGuirk S.M. 2008. Disease management of dairy calves and heifers. Vet. Clin. N. Am. Food Anim. Pract. 24(1):139-156. <http://dx.doi.org/10.1016/j. cvfa.2007.10.003><PMid:18299036>

Mee J.F. 2008. Managing the calf at calving time. JAANP 41:46-53.

Meganck V., Hoflack G., Piepers S. \& Opsomer G. 2015. Evaluation of a protocol to reduce the incidence of neonatal calf diarrhoea on dairy herds. Prev. Vet. Med.118(1):64-70. <http://dx.doi.org/10.1016/j.prevetmed.2014.11.007> $<$ PMid:25475689>

Naciri M., Paul Lefay M., Mancassola R., Poirier P. \& Chermette R. 1999. Role of Cryptosporidium parvum as a pathogen in neonatal diarrhoea complex in suckling and dairy calves in France. Vet. Parasitol. 85(4):245-257.<http:// dx.doi.org/10.1016/S0304-4017(99)00111-9><PMid:10488727>

Novo S.M.F., Freitas R.L., Silva C.P.C., Baldacim V.A.P., Baccili C.C., Reis J.F., Hagiwara M.K. \& Gomes V. 2015. Hematological adaptation in Holstein calves during the neonatal period. Braz. J. Vet. Res. Anim. Sci. 52(3):212216. <http://dx.doi.org/10.11606/issn.1678-4456.v52i3p212-216>
Novo S.M.F., Costa J.F.D.R., Baccili C.C., Sobreira N.M., Silva B.T., de Oliveira P.L., Hurley D.J. \& Gomes V. 2017. Effect of maternal cells transferred with colostrum on the health of neonate calves. Res. Vet. Sci. 112:97-104. <http:// dx.doi.org/10.1016/j.rvsc.2017.01.025> <PMid:28187318>

Ogassawara S. \& Benassi S. 1980. Infecção experimental de gatos com coração de bovino parasitado por Sarcocystis sp. Arqs Inst. Biológico, São Paulo 47:27-32.

Pelkonen S., Romppanen E.L., Siitonen A. \& Pelkonen J. 1994. Differentiation of Salmonella serovar Infantis isolates from human and animal sources by fingerprinting IS200 and 16S rrn loci. J. Clin. Microbiol. 32(9):2128-2133. <http://dx.doi.org/10.1128/JCM.32.9.2128-2133.1994><PMid:7529248>

Poulsen K.P. \& McGuirk S.M. 2009. Respirator disease of the bovine neonate. Vet. Clin. N. Am. Food Anim. Pract. 25(1):121-137, vi-vii. <http://dx.doi. org/10.1016/j.cvfa.2008.10.007> <PMid:19174286>

Rengifo S.A., Silva R.A., Pereira I.A., Zegarra J.Q., Souza M.M. \& Botteon R.D.C.C.M. 2006. Isolamento de agentes microbianos a partir de amostras de sangue e umbigo de bezerros mestiços neonatos. Braz. J. Vet. Res. Anim. Sci. 43(4):442-447.<http://dx.doi.org/10.11606/issn.1678-4456. bjvras.2006.26458>

Rodriguez C.A.R., Brandão P.E., Ferreira F., Gregori F., Buzinaro M.G. \& Jerez J.A. 2004. Improved animal rotavirus isolation in MA104 cells using different trypsin concentrations. Arqs Inst. Biológico, São Paulo 71(4):437-441.

Silva B.T., Henklein A., De Sousa R.M., De Oliveira P.L., Leite S.B.P., Fontes S.M. \& Gomes V. 2016. Vital parameters of Holstein calves from birth to weaning. Revta Bras. Med. Vet. 38(3):299-304.

Silverlås C., De Verdier K., Emanuelson U., Mattsson J.G. \& Björkman C. 2010. Cryptosporidium infection in herds with and without calf diarrhoeal problems. J. Parasitol. Res. 107(6):1435-1444. <http://dx.doi.org/10.1007/ s00436-010-2020- $\mathrm{x}><$ PMid:20714750>

Smith G. 2015. Antimicrobial decision making for enteric diseases of cattle. Vet. Clin. N. Am. Food Anim. Pract. 31(1):47-60, v. <http://dx.doi. org/10.1016/j.cvfa.2014.11.004> <PMid:25705025>

Stanton A.L., Kelton D.F., Leblanc S.J., Millman S.T., Wormuth J., Dingwell R.T. \& Leslie K.E. 2010. The effect of treatment with long-acting antibiotic at postweaning movement on respiratory disease and on growth in commercial dairy calves. J. Dairy Sci. 93(2):574-581. <http://dx.doi.org/10.3168/ jds.2009-2414><PMid:20105529>

Vaziri N.D., Zhao Y.Y. \& Pahl M.V. 2015. Altered intestinal microbial flora and impaired epithelial barrier structure and function in CKD: the nature, mechanisms, consequences and potential treatment. Nephrol. Dial. Transplant. 31(5):737-746. <http://dx.doi.org/10.1093/ndt/gfv095> <PMid:25883197>

Walker W.L., Epperson W.B., Wittum T.E., Lord L.K., Rajala-Schultz P.J. \& Lakritz J. 2012. Characteristics of dairy calf ranches: morbidity, mortality, antibiotic use practices, and biosecurity and biocontainment practices. J. Dairy Sci. 95(4):2204-2214.<http://dx.doi.org/10.3168/jds.2011-4727> <PMid:22459866>

Wang S., Zhu H., Lu C., Kang Z., Luo Y., Feng L. \& Lu X. 2012. Fermented milk supplemented with probiotics and prebiotics can effectively alter the intestinal microbiota and immunity of host animals. J. Dairy Sci. 95(9):4813-4822. <http://dx.doi.org/10.3168/jds.2012-5426> <PMid:22916885>

Windeyer M.C., Leslie K.E., Godden S.M., Hodgins D.C., Lissemore K.D. \& Leblanc S.J. 2014. Factors associated with morbidity, mortality, and growth of dairy heifer calves up to 3 months of age. Prev. Vet. Med. 113(2):231-240.<http://dx.doi.org/10.1016/j.prevetmed.2013.10.019> <PMid:24269039>

Young V.B. \& Schmidt T.M. 2004. Antibiotic-associated diarrhea accompanied by large-scale alterations in the composition of the fecal microbiota. J. Clin. Microbiol. 42(3):1203-1206. <http://dx.doi.org/10.1128/JCM.42.3.12031206.2004><PMid:15004076> 